Bojan Balkovec

\title{
Statements about Žujović and Hebrang from Party Cells
}

In the spring of 1948, relations within the leadership of the Communist Party of Yugoslavia became complicated because of the issue of its attitude towards the Soviet Union. Andrija Hebrang and Sreten Žujović stood out due to their deviation from the line of Josip Broz. ${ }^{1}$ These intense events culminated at the session of the Central Committee of the CPY on 13 April 1948. At this session they formed a commission that was to prepare a report on the anti-party actions of Hebrang and Žujović. The commission included Blagoje Nešković, Ivan Gošnjak and Vida Tomšič.

The commission prepared a six-page report. The Archives of the Republic of Slovenia keep this report in the Janez Vipotnik fonds. ${ }^{2}$ The kept copy is written in the Slovene language. On 9 May 1948, the Politburo of the CPY made an announcement consisting of three parts. The first page is a statement entitled "To All Members of the Communist Party of Yugoslavia”. In it, the Politburo accepts the report from members of the commission and based on the report decides to expel Hebrang and Žujović from the CPY. The next four pages comprise the commission's report on the mistakes made by Hebrang and Žujović. It mentions their mistakes before the war, during the war, and after the war. The wartime mistakes of course include Hebrang's conduct in the Ustasha prison. The many mistakes made after the war are connected with economic development. In the case of Žujović, they also found mistakes from the 1930s. During the war, he made mistakes in the Fifth Enemy Offensive (Sutjeska) and after the war in economic policy. The third part of the report is the decision regarding Hebrang and Žujović from 1946.

Below, I will analyse the statements from the party cells of the Slovene Communist Party regarding the above-mentioned report. Let us begin by trying to establish the

1 For more on the Tito-Stalin conflict and on Hebrang and Žujović, see e.g. Goldstein, Tito, pp. 443-478. and Pirjevec, Tito, Stalin in Zahod, pp. 90-128.

2 SI AS 99 Janez Vipotnik. The report is kept in the technical unit 131. 
number of party members in Slovenia. A few figures are given in the introductory part of the collection of Politburo Minutes, published by Darinka Drnovšek. Drnovšek claims that there were 4,978 members in 1945 . This figure was allegedly based on a report, most likely from August 1945. In 1948, there were said to be as many as 38,635 members. ${ }^{3}$

On 29 February 1948, a session of the Politburo of the Slovene Party was held, and was continued on 5 March 1948. They discussed the Party's status in the countryside. The session minutes record a debate by Janez Hribar ${ }^{4}$. Hribar talked about party cells in the countryside and mentioned 902 cells with 9,095 members. He pointed out the small number of farmers, especially large farmers. There were another 1,344 member candidates in the villages and 7,366 members of the League of Communist Youth of Yugoslavia. In his opinion, farmers accounted for $10 \%$ of all members of the CPS. ${ }^{5}$

The party cells were relatively small. They were organised as territorial cells and as company cells. The local cells in the countryside were limited to settlements, i.e. villages. Some of the village cells had only a few members, sometimes fewer than ten. In the case of larger settlements, they were divided into parts and the cells included members from specific parts of the settlement. For some of the smaller village cells the documents preserved show the exact number of members in a cell because they either mentioned the number of members or the members signed the statement. One example of the members' signatures is the statement from the cell of the village of Kal-Koritnica. The members of the cell signed the second page of the statement. There are six members' signatures on the left-hand side, two signatures on the right and the title Segretar (secretary) above them. A greater number of signatures can be seen e.g. in the statement from the cell in Renče. The first to sign the statement was the cell's secretary. Underneath his signature, which is on the right-hand side of the sheet, they wrote the word Ćlani (members) on the left and made signature lines underneath using a typewriter. However, there were not enough lines. The members signed all the lines then ran out of space, so they signed in a new column to the right of the first one. A few lines have been left blank, though. Perhaps the people signing did not like the relatively narrow space for their signatures, or the first few assumed that they had to leave a line empty for greater legibility. Namely, only the lines two, four and six are empty. Twenty-one members signed this page, and twenty more the back of it. Signature lines are also given on the second page. That page contains only one "mistake" - a person signed on the same line as the one before him. ${ }^{6}$

3 Drnovšek, Zapisniki politbiroja CK KPS/ZKS, 1945-1954, p. 9.

4 Hribar, Janez, Enciklopedija Slovenije. In the government appointed on 5 May 1945, Hribar acted as the minister of agriculture. From August 1947 onward he was a minister without portfolio and the chairman of the commission for cooperatives in the government of the People's Republic of Slovenia. Uradni list Ljudske republike Slovenije, Year IV, No 35, August 23 1947, notice number 198.

5 Drnovšek, Zapisniki politbiroja CK KPS/ZKS, 1945-1954, p. 102.

6 Krajevna celica KPS Renče, CENTRALNEMU KOMITETU KOMUNISTIČNE PARTIJE JUGOSLAVIJE BEOGRAD, Renče dne 24 maja 1948 in Centralnemu komitetu K.P.J. Beograd, Dne 16-5-1948 (letter from the Kal-Koritnica cell). SI AS 1589 Centralni komite Komunistične partije Slovenije, box 6. 
Company cells were active in all sectors of the economy. In large companies, cells could be organised by individual plants and then hierarchically upgraded to a sort of company party leadership. In the case of construction companies, cells could also be organised by work sites. Cells were present in the industry, cooperatives, commerce, the education system, and administration. Cells in secondary schools could also have students as their members.

I used both boxes kept by the Archives of the Republic of Slovenia to analyse the statements from cells. ${ }^{7}$ The boxes are a part of the Central Committee of the CPS fonds. The inventory is not entirely accurate and the boxes were not that easy to find. Each box contains a folder with sheets containing statements from party cells. In total, the two boxes contain just over 1,850 statements from party cells.

There is too much material in the boxes and it would be sensible to divide it into three boxes. The material is in a relatively good condition, mostly tear-free; however, some of the sheets are folded because of the format. A few effects of their age and of the used type of paper and ink are noticeable. These elements can help us determine what kind of paper was used (format, thickness) and what kind of ink. As regards the contents of the statements, let me mention the most common elements that can be analysed. In general, the statements have three substantive parts. The introductory part contains the recipient's address and/or the document title. Usually, the name of the addressee was written on the statement and sometimes also the title of the document. Only exceptionally was the date dropped; it was usually written at the beginning of the statements, sometimes also in the introductory sentence. The body of the statement explains the reasons for the meeting, the cell's decision regarding the commission's report on Hebrang and Žujović, the cell's attitude towards the sentence, its attitude towards party discipline and the cell's promises. The promises are also sometimes included in the final part of the document or combined with the salutations. The final part of the document consists of salutations and various signatures.

Different types of paper were used for the statements. Most often, white A4 sheets were used. More than seventy years later, it is difficult to assess the whiteness of the paper, for even the quality of first-rate, pure and white paper can diminish simply because a lot of time has passed. The so-called lengthened A4 format is not that rare. It was a paper format slightly longer than the current standard A4 format and was the most commonly used paper format in Europe before the introduction of today's standards. The sheets of this format could be loose or in the form of folded sheets. Some of the folded sheets are most likely letter writing paper, based on their size and shape. The limited access to paper is also evident from the statements written on ruled sheets, for which we can reasonably deduce that they had been torn out of notebooks. ${ }^{8}$ It was most

7 SI AS 1589 Centralni komite Komunistične partije Slovenije A.E, 296, boxes 6 and 7.

8 Člani celice Notr. gorice, SI AS 1589 Centralni komite Komunistične partije Slovenije, box 6. 
likely the only type of paper they had. The statements were also written on white paper of smaller formats, e.g. A5, and on non-standard formats. All of the above-mentioned types of paper are either blank, ruled or squared. A special type of blank sheets was that with pre-printed headers. The pre-printed sheets contain the names of institutions, such as DISTRICT COMMITTEE OF CPS Trbovlje, TOWN COMMITTEE OF CPS MARIBOR or LOCAL UNION COUNCIL CELJE 9 . All three examples have a pre-printed name of the institution, the name of the place, and a space for the date. The text on the forms from Trbovlje and Celje is red, while the one on the form from Maribor is black. The Trbovlje form does not have a logotype, while the Maribor form has the CP logotype, a red star with a white hammer and sickle within the star. The document from Celje bears the union emblem in red.

The statements were written by hand or typed on a typewriter. In box six, the ratio between the handwritten and typed statements is roughly 40:60. The same holds true for box seven. The handwritten statements are sometimes written in the awkward handwriting of someone not used to writing. ${ }^{10}$ The aforementioned statement from the village of Poletiči has two sheets. It seems that one of the two is in fact an unfinished beginning of a statement. Only the name of the addressee is written on the second sheet; this time the initials are "K.P.S." (CPS), but on the sheet on which the statement is written, the initials are "K.P."The sheet without a statement contains the date of the statement, which the sheet with the statement does not. The handwriting is very awkward; the writer was unable to write in a straight line on a blank sheet. The text is also linguistically poor; letters are missing from certain words, and capital letters are used inaccurately.

The text is written in pencil. Handwritten statements were often written in pencil. Pens were also used. The exact opposite of the statements described above are those in which the writer made an effort and attempted to highlight the text's meaning with its form. Such handwriting is not only legible, it actually borders on calligraphy ${ }^{11}$. Ink colours must have varied because this is noticeable in the preserved material. Of course, we must take into account that a specific type of ink may have changed its hue due to external influences. The current condition of the various inks indicates that the handwritten statements were written in black, blue, red, violet and green. A few examples have been preserved where it seems that dual hues were used, namely greenish blue and greenish black. There are two possible reasons for this. Perhaps two inks were mixed; the first ink ran out and was replaced by an ink of a different colour. Another reason could be

9 OKRAJNI KOMITET KPS TRBOVLJE, Centralnemu komitetu KPS Ljubljana, Trbovlje, 22. maja 1948, MESTNI KOMITETT KPS MARIBOR, DRAGI NAŠ TOVARIŠ TITO!, Maribor, 26. maj 1948 in KRAJEVNI SINDIKALNI SVET CELJE, CENTRALNEMU KOMITETU KP JUGOSLAVIJE BEOGRAD, Celje, dne 19. maja 1948. SI AS 1589 Centralni komite Komunistične partije Slovenije, box 6.

10 Celica K.P. vas Polotiči okraj Sežana. SI AS 1589 Centralni komite Komunistične partije Slovenije, box 7.

11 Centralnemu komitetu K.P.J., Beograd, Bosljiva loka, dne 17. maja 1948. SI AS 1589 Centralni komite Komunistične partije Slovenije, box 7 . 
chemical changes that affected the inks after 1948. In addition to pens and various inks, pencils were also used and at least two types of coloured pencils at that - blue and red/ violet. The latter was in fact quite commonly used. This pencil was blue on one end and red or violet on the other. In the handwritten statements there are no major differences between the texts of the statements and the signatures.

The typed statements reveal the various conditions of the typewriters used. Many typewriters had a worn-out ink ribbon, which is why the impression is very pale. Since there was a shortage, people were allowed to use ribbons of different colours, which is why quite a few statements are typed, for example, in red. The linguistic suitability of typewriters also varied. Many of them did not have the special letters of the Slovene alphabet. There are two possible explanations for this. If a territory had been part of Italy before the war, then they might have used old, pre-war typewriters. Namely, the Italian ones did not have special Slovene letters. Nor did the typewriters from the German occupation zones. But they did find a typewriter or two somewhere that dated back to the pre-war Yugoslavia and were linguistically suitable. The use of typewriters without Slovene letters is easily noticed. If carons were added to the letters $\mathrm{c}, \mathrm{s}$ and $\mathrm{z}$ in a typed statement, then one of those typewriters was used. Of course, there are also statements that were typed using such typewriters, but no carons were added.

The preserved material from the Politburo and the Central Committee of the Communist Party contains no instructions to party cells to give their support to the measures taken against Hebrang and Žujović. I have inferred the existence of such an instruction from a letter sent by the District Committee of CPS Trbovlje to the Central Committee of CPY. This district committee sent the Central Committee 70 reports in support of the resolution adopted by the party cells in the district.

"Enclosed is the material regarding the expulsion from the Party of Comrade A. Hebrang and S. Žujević, which was given to the District Committee of CPS to be studied by the cells. We are returning the material from numbers 25626 to 25655 , inclusive.

Also enclosed are 70 resolutions, prepared by the cells where the members were given interpretations of the decisions of the Politburo of the CC CPY. Please confirm the receipt of this material." ${ }^{2}$

These statements were made after 9 May 1948. The oldest one is dated the following day. It was written at the Hrastnik glassworks. ${ }^{13}$ Most of the statements are from

12 OKRAJNI KOMITETE KPS TRBOVLJE, Trbovlje, dne 22. maj 1948. SI AS 1589 Centralni komite Komunistične partije Slovenije, box 6 .

13 Centralnemu komitetu K.P.J. Beograd, Hrastnik, dne 10.5.1948. SI AS 1589 Centralni komite Komunistične partije Slovenije, box 6. 
May 1948, and a few from the first days of June. The meetings at which they read the decision regarding the expulsion and debated it were held every day of the week, including Sundays. In a few statements, the time of the meeting is also given. One such example is the statement from the Dob cell, whose introductory sentence mentions that they convened for a special meeting on 16 May 1948 at 9 a.m. on the premises of the Local People's Committee. The meeting was easily held at 9 a.m. because it was a Sunday. ${ }^{14} \mathrm{On}$ working days the meetings were usually held in the afternoon, outside working hours.

The statement usually ended with a salutation and signature. I have already said a few words about signatures in the paragraph on ink and writing. The signature was usually that of the cell's secretary. Usually it was only a signature; only rarely was the secretary's name typed next to it or written in another way. If the statement was a joint statement from several cells, usually all of the secretaries signed it. Some of the signatures are easily legible, while some make it impossible to decipher the signatory's name or, even more often, the surname. As has already been mentioned, the statements could also be signed by all the present members of the cell. Sometimes there are only a few signatures, often fewer than ten in the statements from the countryside. An exact opposite is e.g. the statement from the local cell in Renče, which I have already mentioned, ${ }^{15}$ and the statement from the Communists of the Department of Mining probably at a school (we cannot recognize the name) in Ljubljana ${ }^{16}$. The former was signed by 41 members and the latter by 32 . No secretary signed the second statement. On the first page, the statement ends with the salutation "Smrt fašizmu - svoboda narodu" (Death to Fascism - Freedom to the People) and a sort of signature "Komunisti rudarskega oddelka na FSŠ v Ljubljani” (Communists of the Department of Mining at the ... in Ljubljana). On the second page containing the signatures, none of them mention the function of cell secretary.

A peculiarity of these two statements is their form. They are not written as the minutes of a meeting, but as a letter from a party cell to a higher-ranking body. This is corroborated by the beginning of the document, in which they wrote the addressee, and by the conclusion, where they added salutations. In most documents the addressee was the Central Committee of the CPY. However, the ways the addressee is written vary greatly. The words "Centralni komitet" (Central Committee) was sometimes written in the usual way, i.e. "Centralni" in upper case and "komitet" in lower case. It is not that rare for both words to be written in upper case. This most likely has to do with the

14 Celica KPS Okraj Kamnik, Dob, 16.V. 1948. SI AS 1589 Centralni komite Komunistične partije Slovenije, box 6.

15 Krajevna celica KPS Renče, CENTRALNEMU KOMITETU KOMUNISTIČNE PARTIJE JUGOSLAVIJE BEOGRAD, Renče dne 24 maja 1948. SI AS 1589 Centralni komite Komunistične partije Slovenije, box 6.

16 Resolucija. Centralnemu komitetu KPJ Beograd. Ljubljana, 21. V.1948. SI AS 1589 Centralni komite Komunistične partije Slovenije, box 6 . 
writers' desire to demonstrate the importance of the document. The writers of the minutes sometimes resorted to using the acronym "CK" $(\mathrm{CC})$. The acronym "KPJ" (CPY) is written in several ways, most often as "KPJ", though sometimes they wrote a full stop after each letter ("K.P.J."). Belgrade is also frequently mentioned as the head office of the body addressed. If the writers of the statement were not satisfied with merely addressing the Central Committee, they also added the word "resolucija" (resolution). That word was also written in different ways. In the typed statements the word "resolucija" is written as e.g. Resolucija, RESOLUCIJA, RE S O L U C IJ A. The word "Resolucija" was usually followed by the words "Centralnemu komitetu KPJ" (To the Central Committee of the CPY), again written in different ways. A special way of addressing can be seen in the statement prepared by the Vir cell. As we can see, they began with the introductory sentence, in which they mentioned the addressee, the reason for preparing the statement, and only afterwards wrote that they were adopting the resolution.

"CPS Cell Vir pri Domžalah. Vir, on 19 May 1948, At this special meeting, in light of the presented actions against the state and plotting from members of CC CPY, we, members of the CPS Cell Vir pri Domžalah, the members gathered (in the field), propose the following RE S O L UT I O N ! ${ }^{17}$

Even more interesting is the salutation, which was only exceptionally left out. In fact, there are roughly three types of salutations. In the first group are salutations that can be recognised as such by their form or usage. In the second group are salutations in the form of exclamations, such as "Naj živi..." (Long live ...) or the word "pozdrav" (salute) with the prefix "Tovariški" (comrade), and the like. In the third group are salutations that look more like promises or oaths. This last type can be supplemented by oaths and promises given in the body of the statement. There are also examples when a promise or oath is mentioned only at the bottom as a salutation. Among rather standard salutations is the salutation "Smrt fašizmu - Svoboda narodu" (Death to Fascism - Freedom to the People), which was already in use during World War II. ${ }^{18}$ This salutation could be written in many ways. The first two words were always the same, but the last two could be spelled "Svobodo narodu". This salutation often ended with an exclamation mark. Sometimes it was shortened to "SF - SN". Another comparable expression is "borben pozdrav" (a fighting salute). This one can also be found in the bodies of statements.

17 KPS Celica Vir pri Domžalah. Vir, dne 19. maja 1948. SI AS 1589 Centralni komite Komunistične partije Slovenije, box 6.

18 „Smrt fašizmu - sloboda narodu!“; Hladnik - Milharčič, „Alojz Kajin“. 
Various phrases were added to the salutation "Naj živi” (Long live) or "Živel”(Hail). The phrases were mostly connected with Tito and the (CC) (Politburo) of the CPY. The salutation to Tito was either a simple "Naj živi tovariš Tito" (Long live Comrade Tito), in which the name Tito was often spelled in upper case or in upper case and spaced. Of course, such a salutation could be longer and more detailed. It could praise Tito's leadership skills e.g. "Živel naš voditelj tov. maršal Tito" (Hail our leader Comrade Marshal Tito) ${ }^{19}$, NAJ ŽIVI NAŠ VELIKI VODITELJ Tor. T I T O SEKRETAR CENTRALNEGA KOMITETA KPJJUGOSLAVIJE! (LONG LIVE OUR GREAT LEADER Comrade T I T O SECRETARY OF THE CENTRAL COMMITTEE OF THE CP OF YUGOSLAVIA!) 20 "Naj živi Centralni Komitet in Komunistična Partija Jugoslavije pod modrim vodstvom in borcem za pravice delovnega ljudstva MARŠAL TITO" (Long live the Central Committee and the Communist Party of Yugoslavia under the wise leadership of the fighter for the rights of the working people MARSHAL TITO $)^{21}$. Tito was hailed as a teacher, e.g. "Naj živi Maršal Tito buditelj in učitelj jugoslovanskih narodov" (Long live Marshal Tito, the awakener and teacher of Yugoslav nations),"Naj živi naš vodja in učitelj tvorec vseh naših zmag maršal Jugoslavije tovariš T I T O" (Long live our leader and teacher, the author of all our victories, the Marshal of Yugoslavia, Comrade T I T O), and “Naj živi močna in monolitna K.P. Jugoslavije, ki nas neomajno vodi v socializem" (Long live the strong and monolithic CP of Yugoslavia, which is leading us steadfastly towards socialism) ${ }^{22}$. Tito was hailed as a comrade in arms, e.g. Z Titom v borbi $-z$ Titom $v$ miru (With Tito in battle - with Tito in peace) - the original text contains some spelling mistakes. ${ }^{23}$ Let me mention a linguistic peculiarity in the statements from the Primorska region, namely the frequent use of the word segretar instead of sekretar (meaning "secretary"). This spelling was of course influenced by the Italian word for this function. The word was also used in salutations, e.g. "Naj živi Segretar KPJ Maršal Tito" (Long live the Secretary of the CPY Marshal Tito) ${ }^{24}$. Some of the cells were quite harsh and direct in their statements, and some in the salutations,

19 RESOLUCIJA, CENTRALNEMU KOMITETU KOMUNISTIČNE PARTIJE V BEOGRADU., LJUBLJANA 20. MAJA 1948. SI AS 1589 Centralni komite Komunistične partije Slovenije, box 6. The original contains the misspelled word "vodotel" instead of "voditelj" (leader). The statement was sent by the cell at the cannery in Vič, Ljubljana.

20 CENTRALNEMU KOMITETU KPJ BEOGRAD. DUPLICA, DNE 17. MAJA 1948. SI AS 1589 Centralni komite Komunistične partije Slovenije, box 6.

21 Partijska celica : Sekcija za zveze in varnostne naprave, Ljubljana - Šiška. SI AS 1589 Centralni komite Komunistične partije Slovenije, box 6 .

22 Celica baza za repatricijo izseljencev - Kamnik, Kamnik, dne 21. V. 1948. SI AS 1589 Centralni komite Komunistične partije Slovenije, box 6. The last two salutations are two out of four in the same statement. Also added were "Naj živi C.K.K.P.J!" (Long live CC CPY!) and "Smrt fašizmu - svobodo narodu!" (Death to Fascism Freedom to the People!.

23 AKTIV KOMUNISTOV UPRAVE NM za gl. mesto LJUBLJANA. Ljubljana, 24. maja 1948. SI AS 1589 Centralni komite Komunistične partije Slovenije, box 6.

24 Krajevna celica Vrhovlje, Vrhovlje 1. VI.1948. SI AS 1589 Centralni komite Komunistične partije Slovenije, box 6. 
as well. The cell in Križe concluded its resolution, addressed to the Central Committee of the CPY with a misprint ("Centralni kometet KPJ"), with two salutations. In the first it called for "SMRT VSEM SOVRAŽNIKOM NAŠE PARTIJE, ARMIJE IN NARODA!" (DEATH TO ALL ENEMIES OF OUR PARTY, ARMY AND NATION!). Then it greeted the CC CPY and Tito with "ŽIVEL CENTRALNI KOMITE KOMUNISTIČNE PARTIJE JUGOSLAVIJE NA ČELU S TOVARIŠEM TITOM!" (HAIL THE CENTRAL COMMITTEE OF THE COMMUNIST PARTY OF YUGOSLAVIA, LED BY COMRADE TITO!). ${ }^{25}$ In salutations, they also mentioned the path towards socialism under party leadership, class struggle, the five-year plan, the FPRY, and glorified labour with "Delu čast in oblast!" (Honour and Power to Labour!). ${ }^{26} \mathrm{I}$ will mention three more salutations. The first one is interesting due to the political circumstances at the time. The relations between the Soviet Union and Yugoslavia were no longer idyllic, which is why the salutation "Naj živi velika partija Lenina - Stalina! (Long live the great party of Lenin - Stalin!)” ${ }^{27}$ from late May 1948 is interesting. Such expressions are rare in the analysed statements. Another statement is an interesting rare example of party members greeting the party commission that wrote the report on Hebrang and Žujović. Members of the cell in the village of Brestje in the region of Goriška Brda wrote four "Naj živi” (Long live) salutations. The first three are reserved for Marshal Tito, the party and the committee (they probably forgot to write the word "Centralni/Central" in front of "committee"). The last salutation goes: "Naj zivi raziskovalna komisija, saboterjev in omadezevalcev KP.!” (Long live the research commission into saboteurs and tarnishers of the CP!) - in the original, the carons on the letter $\check{z}$ are missing. ${ }^{28}$

The third example are salutations which mention death. The Breginj cell concluded its statement with three salutations. The first is "Smrt saboterjem in izmečkom našega naroda!" (Death to the saboteurs and dregs of our nation!). This is followed by two more salutations: "Naj živi naša KP pod trdnim vodstvom maršala Tita!" (Long live our CP under the firm leadership of Marshal Tito!) and the rare "Naj živi FLRJ pod vodstvom naše slavne KP!" (Long live the FPRY under the leadership of our glorious CP!). ${ }^{29}$ Two similar salutations are "Smrt saboterjem!" (Death to saboteurs!) ${ }^{30}$ and the salutation

25 CENTRALNEMU KOMETETU K.P.J. Beograd. Križe 22. maja 1948. SI AS 1589 Centralni komite Komunistične partije Slovenije, box 6 .

26 CENTRALNEMU KOMITETU KPJ. BEOGRAD. Ljubljana, 20. maja 1948. SI AS 1589 Centralni komite Komunistične partije Slovenije, box 6. A statement from the cell of the Secretariat Group of the Directorate-General for the Exploitation of Railways Ljubljana.

27 Celica : Tovarna dek. tkanin Ljubljana. Ljubljana, dne 20. V. 1948. SI AS 1589 Centralni komite Komunistične partije Slovenije, box 6.

28 Resolucija. SI AS 1589 Centralni komite Komunistične partije Slovenije, box 6. The date of the meeting, 6 June 1948 , is written in the first sentence of the resolution. The typewriter did not have letters with carons.

29 Partijska celica Breginj, dne 20. maja 1948. SI AS 1589 Centralni komite Komunistične partije Slovenije, box 6.

30 Krajevna celica K.P.S. Vrhpolje 3.6.1948. SI AS 1589 Centralni komite Komunistične partije Slovenije, box 6. 
from the Križe cell, calling for death of opponents of the Party, army and the nation, which has already been mentioned.

In a way, these salutations showed the writers' resourcefulness. They used the salutations to emphasise their resolve or to show that they were truly on the right path.

The statements from cells differ in contents and in the intensity of the expressions used. The length of the text is also connected with this. Some statements contain only a few lines. One such example is the statement from the local party cell in Radomlje, a smaller town in the vicinity of Ljubljana. They summed up their agreement with the decision of the Central Committee of the CPY in three lines. On the other hand, there is another statement two pages long. The Cerovo local cell wrote a two-page statement by hand. Had it been typed, it would probably take up only one page; however, there are also typed statements that are two pages long.

Linguistic mistakes have already been mentioned. They indicate, among other thin$\mathrm{gs}$, the different levels of education among party members. Those with primary education, who performed various types of manual labour, were surely less skilled in linguistic expression, because they rarely expressed themselves in writing. A few linguistic mistakes or peculiarities have also been encountered.

The first peculiarity or awkwardness, or perhaps even a lack of knowledge of the Croatian or Serbian language, can be seen in the spelling of names. Generally, there are three mistakes. Other kinds of mistakes encountered were mainly misprints. The most common mistake is incorrectly writing the surname Žujević instead of Žujović. Not only was Žujović's last name changed, but so was his first name. Thus Sreten became Sretan. The name Sreten is said to originate from the word sretan = happy, which means that the meaning of Žujovićs name was not changed. This mistake surely did not occur because of their knowledge of the etymology of the name Sreten, but because of carelessness or unfamiliarity with the name in the Slovene environment. Hebrang's name was also changed. Instead of the Croatian Andrija he became the Slovene Andrej. Interestingly, in some places they altered the surname Hebrang. In Žujović's case they changed one letter, but in Hebrang's case they added one. The spelling Hembrang is not that rare. The cell from the Straža factory wrote its resolution by hand and wrote both surnames in the title, making a mistake in both of them. They turned Hebrang into Hembrang and Žujović into Žujevič. ${ }^{31}$ In its statement, the cell from the Novo Mesto people's town committee mentioned both men in two sentences by their first and last names. They are written the same in both cases, but awkwardly, entirely incorrectly. The first and last names are both wrong. Andrija Hebrang became Adria Hebran and Sreten Žujović became Žujevič Sretan. As we can see, they arranged the first and last names unusually. They used the correct sequence of the first name, followed by the last

31 Resolucija o zadevi Hembrang - Žujevič. Straža, dne 19. V. 1948. SI AS 1589 Centralni komite Komunistične partije Slovenije, box 6. 
name in the case of Hebrang, but immediately afterwards the incorrect sequence of the last name, followed by the first name in the case of Žujović. ${ }^{32}$ There is even an example where the surname Hebrang is written several times in a single statement in different ways. As for the surname Žujović, they did not bother with the letter ć. Usually they simply wrote Žujovič.

In statements from places that were part of Italy before the war, we see the Italian-sounding word segretar instead of the Slovene sekretar. The various spellings found in titles and salutations that are linguistic mistakes were intentional. This includes, for example, writing in upper case, with which they wanted to highlight a title or salutation, or an exclamation within a salutation.

The statements are of various lengths, which means that they used either many or fewer words to agree with the mistakes made by Hebrang and Žujović. The cells either simply stated that they agree with the condemnation of their mistakes, or they also enumerated those mistakes. In such cases they added statements that corroborated their attitude and wrote that they unanimously condemn the criminal acts, "We strongly condemn Hebrang's chauvinistic acts with which he intended to break up the brotherhood and unity of our Yugoslav nations." ${ }^{33}$ They condemned libelling Tito ${ }^{34}$, "the criminal acts against the Party and state." ${ }^{35}$ Sometimes, their condemnation was not enough, so they took it a step further and wrote "in disgust, we condemn anti-party actions." ${ }^{36}$ When agreeing with the decision, they also wrote down their various opinions. They pointed out the battle for socialism, the attainment of the five-year plan, economic development, brotherhood and unity, many victims of the war, the desecration of war victims, and great efforts towards economic development. They expressed their disagreement with factionists, even mentioning Trotskyist factionists, ${ }^{37}$ with anti-party actions and ambition; and they acknowledged the purity of the Party. They expressed their contempt, saying that such bad actions could only be performed by someone more interested in personal gain than in the benefit of the community. Some cells even resorted to pointing out the special nature of the Yugoslav Party. Members of the cell at Ljudska prosveta Slovenije (People's Education Society of Slovenia) sent the CC CPY “expressions of their firm belief in the correctness of the political line led by the CC CPY based on

32 Celica Mestnega L.O. Novo mesto, Dne 17.V. 1948. SI AS 1589 Centralni komite Komunistične partije Slovenije, box 6.

33 Celica Podgrad, dne 18.5.1948. SI AS 1589 Centralni komite Komunistične partije Slovenije, box 6.

34 Centralnemu komitetu Komunistične partije Jugoslavije. V Novem mestu, 17. V. 1948. SI AS 1589 Centralni komite Komunistične partije Slovenije, box 6.

35 Partijska celica KPJ Bršljin - Novo mesto. Bršljin 17.V. 1948. SI AS 1589 Centralni komite Komunistične partije Slovenije, box 6 .

36 Celica Jama Hrastnik, Hrastnik, 18. 5.1948, SI AS 1589 Centralni komite Komunistične partije Slovenije, box 6.

37 Celica okrožnega inšpeltorata kontrolne komisije, Novo mesto. SI AS 1589 Centralni komite Komunistične partije Slovenije, box 6 . 
a Leninist analysis of the specific nature of the historical and social conditions of the nations of Yugoslavia, and on the awareness of the active role of Tito's Yugoslavia in the struggle for peace and a powerful people's democracy in the world, led by the world's working masses under the leadership of the great SU." 38 Many were unable to compose such sentences, yet there were quite a few who resorted to such communist phraseology.

An important element of the statements were the various promises given by the cells. The most common promise was that of vigilance in their own ranks, in order to prevent the appearance of similar elements and destroyers, like Hebrang and Žujović; of making sure the Party lines stay pure; of strengthening democracy; of educating themselves ideologically; of staying vigilant; of defending the achievements of the National Liberation Struggle; and of fighting against idleness. They substantiated their promises by giving "a solemn Party pledge to steadily walk the line led by the Central Committee of the CPY and to not allow anyone to dishonour our guide, the Communist Party." ${ }^{39}$ Sometimes, the contents of the promise were more detailed, which mostly depended on the environment in which the cell operated. Companies pledged to invest all their efforts into realising the five-year plans and similar economic goals. "We undertake to further strengthen our ranks and to increase our vigilance against all who would harm or hinder the implementation of our five-year plan./.../ and we undertake to consistently fight for the quick attainment of socialism." ${ }^{40}$ Educational workers from Zagorje ob Savi wrote the following: "As educational workers we will dedicate all our future efforts to raising the cultural level of our people." ${ }^{41}$ Members of the CPS cell at Ljudska prosveta Slovenije wrote the following: "We are aware of the urgent task of Ljudska prosveta Slovenije in view of the heavy burden of clerical, social democratic and other reactionary residues that serve the imperialist agencies beyond the nearby borders as bases for the battle against the building of socialism and a socialist culture in our parts. We are aware of the delicate nature of our ideological front, of the great damage that would be caused by straying from the right path of our Party, by any opportunism, by any weakening of the unity of the Liberation Front right here, on the ideological front. We therefore pledge to invest all our efforts into building our ideology; all our efforts into the battle for great ideological purity and quality of the people's education in Slovenia." ${ }^{42}$ The cell of the

38 Celica KPS pri ustanovi Ljudska prosveta Slovenije. Ljubljana, dne 25. 5. 1948. SI AS 1589 Centralni komite Komunistične partije Slovenije, box 6. In the header the members of the cell felt it was important to mention that the cell had 5 members and that 4 were present at the meeting.

39 Centralnemu komitetu Komunistične Partije Jugoslavije, Novo mesto, dne 17. V. 1948 SI AS 1589 Centralni komite Komunistične partije Slovenije, box 6. A statement from the members of the cell at the District Committee of CPS Novo mesto.

40 CELICA KPS JUGOPETROL-LJUBLJANA. RESOLUCIJA CENTRALNEMU KOMITEJU KOMUNISTIČNE PARTIJE JUGOSLAVIJE. SI AS 1589 Centralni komite Komunistične partije Slovenije, box 6.

41 CENTRALNEMU KOMITETU KOMUNISTIČNE PARTIJE JUGOSLAVIJE. SI AS 1589 Centralni komite Komunistične partije Slovenije, box 6. A statement from the cell of educational workers from Zagorje ob Savi.

42 Celica KPS pri ustanovi Ljudska prosveta Slovenije. Ljubljana, dne 25. 5. 1948 SI AS 1589 Centralni komite Komunistične partije Slovenije, box 6. 
joiner's cooperative Št. Vid pri Vipavi imbued its statement with a simple pedagogical element of the home or family environment. The purpose of punishment is to convince the offender that making mistakes does not pay. "The cell fully agrees that the aforementioned comrades are severely punished so they would no longer want to eat away at the healthy roots that have reached their goal in such an exhausted state." ${ }^{43}$

Such expressions of opinion were often intertwined with statements regarding the sentence proposed for Hebrang and Žujović. As for their opinions on the type and degree of punishment, roughly two kinds can be observed. The first option was to include substantive mentions of their culpability in the statement, repeating the contents of the commission's report. Based on their personal beliefs, they also added some of the things mentioned in the examples above.

Lastly, let me point out an element which undoubtedly reflects the zeitgeist: how the party cells stated their opinions on the sentence. Some cells felt it was enough to write that Hebrang and Žujović should be expelled, while others took it a step further by expressing their enthusiasm for the proposal. "We strongly condemn their anti-Party actions and enthusiastically welcome the proposal of the party commission and the decision of the Politburo of CC CPY to expel the two harmful elements from the Party." ${ }^{44}$ About half of the cells were not satisfied with their expulsion; instead they proposed that they be handed over to the people's court. Certain statements show that people did not fully understand the structure of the judicial system. For instance, the cell at the factory of musical instruments in Mengeš proposed that they be handed over to the $\mathrm{Su}-$ preme Court and not to a court of first instance. ${ }^{45}$ As for the sentence, they all expected that it would be just. Of course, it is impossible to determine what they considered a just sentence. In some statements, it can be inferred that a just sentence is a sentence in accordance with the law. When stating their opinion on the severity of the sentence, most of them only mention a severe sentence or a sentence in accordance with the law. Quite often, they wrote that they should be punished as severely as the law allows. They added that such criminals deserved such punishment. Hebrang and Žujović were also called by other names, often as the dregs of the Party or the dregs of the nation. "We demand that such elements be punished with the severest sentence, so our Party will remain pure and free of the dregs of the nation." ${ }^{46}$ The statement from the Vrhpolje-Duplje cell also contained thoughts on a Communist as a person with high moral standards. Whoever violates those standards should be punished more severely. "Even though a true

43 Celica KPS mizarske zadruge Št. Vid pri Vipavi. Št. Vid, 7. junij 1948. SI AS 1589 Centralni komite Komunistične partije Slovenije, box 6 .

44 Centralnemu komitetu KPJ Beograd. Dole, 18. 5. 1948. SI AS 1589 Centralni komite Komunistične partije Slovenije, box 6.

45 Celica KP TOVARNA GLASBIL MENGEŠ. Mengeš, dne 20./5. 1948. SI AS 1589 Centralni komite Komunistične partije Slovenije, box 6.

46 Partijska celica Breginj, dne 20. maja 1948. SI AS 1589 Centralni komite Komunistične partije Slovenije, box 6. 
Communist would be punished enough by expulsion alone, we do not consider it sufficient in this case because we do not consider people working against the $\mathrm{CP}$, i.e. against our people's government, i.e. against the entire internal structure, to be true Communists. We consider such people to be the worst criminals and therefore demand the most severe sentence for them." ${ }^{17}$ In some cases they even demanded that they be punished most severely, by death. They demanded the death penalty with surprising ease. This is interesting because not that long ago death was virtually everywhere. Namely, only three years had passed since the end of World War II. On the other hand, at that time people expected determination and strictness. What better way to demonstrate your orthodoxy than by giving the most radical statements, which were to prove the decisiveness of the members and their support for the leadership. The cell from Kozana wrote that it would not allow a mild sentence to be imposed on them, and that they deserved to die for their actions. In their opinion, all the citizens of the FPRY should demand the same. ${ }^{48}$ Not many cells demanded the death penalty in their statements explicitly. However, we have no way of knowing what many of the cells meant in their statements when they wrote that they should be punished most severely. The most severe sentence could, of course, mean the death penalty, or merely the longest possible prison sentence.

\section{Sources and literature}

\section{Archival sources}

SI AS 99 Janez Vipotnik, SI AS 99/131 Poročilo in predlog partijske komisije v zadevi Sretena Žujovića in Andrije Hebranga - izključitev, 1948.05.09. Arhiv Republike Slovenije. http:// arsq.gov.si/Query/detail.aspx?id=371961.

SI AS 1589 Centralni komite Komunistične partije Slovenije.

\section{Literature}

Drnovšek, Darinka, Zapisniki politbiroja CK KPS/ZKS, 1945-1954. Viri 15. Ljubljana: Arhivsko društvo Slovenije, 2000.

Enciklopedija Slovenije. Ljubljana: Mladinska knjiga, b. d.

Goldstein, Ivo i Slavko Goldstein, Tito. 1. izdanje. Zagreb: Profil, 2015.

Hladnik - Milharčič, Ervin, Alojz Kajin: Mi smo se uprli okupatorju, oni so se z njim borili proti nam. Kaj tukaj ni jasnega? Dnevnik, 9. maj 2015. https://www.dnevnik.si/1042712553.

Pirjevec, Jože, Tito, Stalin in Zahod. 1. natis v slovenščini. Zbirka Družboslovje. Ljubljana: Delavska enotnost, 1987.

47 Krajevna celica K.P.S. Vrhpolje in Duplje. Vrhpolje 3.6.49. SI AS 1589 Centralni komitet Komunistične partije Slovenije, box 6.

48 CENTRALNEMU KOMITETU KOMUNISTIČNE PARTIJE JUGOSLAVIJE. KRAJEVNA CELICA KOZANA DNE 28. MAJA 1948. SI AS 1589 Centralni komite Komunistične partije Slovenije, box 6. 
Smrt fašizmu - sloboda narodu! Wikipedia, 20. avgust 2018. https://sh.wikipedia.org/w/index. php?title=Smrt_fa\%C5\%A1izmu_-_sloboda_narodu!\&oldid=40841706.

Uradni list Ljudske republike Slovenije.

\section{Summary}

Bojan Balkovec

\section{Statements about Žujović and Hebrang from Party Cells}

The CC CPS fonds at the Archives of the Republic of Slovenia contains two boxes with approximately 1850 statements from party cells regarding the Hebrang and Žujović affair. In their statements, the party cells supported the decision regarding the expulsion of Hebrang and $\check{Z}_{\mathrm{u}-}$ jovic from the Party. The statements were either typed or written by hand on different types of paper and in different inks or pencils. Some of the statements are brief and merely sum up the Party's resolution. The statements often abound in phrases and sentences with which the cells substantiated them. Such substantiations are undoubtedly connected with the desire to prove their orthodoxy. When giving their opinions on the punishment, a great number of statements also demand a court sentence; in some cases, explicitly the death penalty. 